\title{
In Vitro Anticancer, Antimicrobial and Antioxidant Screening Of Compounds from Ricinus Communis Linn: A Review
}

\author{
Constantine Kameti, Dr. Henry Mwangi, Dr. Margaret Ng'ang'a
}

\begin{abstract}
Medicinal plants have been in use since ancient times in the treatment of diseases such as stomach ache, diarrhoea, sexually transmitted diseases, tumours and wounds among others. The family Euphorbiaceae contains approximately 350 genera and over 7,500 species that are flowering plants. Amongst the plants is the Ricinus communis Linn. or castor plant which has high traditional and medicinal values leading to a healthy free disease community. In Kenya, about 25 million people are known to rely on herbal medicine. Moreover, herbal drugs are known to be more accessible and preferred due to their natural source and presumed comparative lesser side effect. Numerous studies on phytochemical composition of $R$. communis and pharmacological have been conducted. In the recent past, scientists and researchers around the globe have elaborately studied the phytochemical composition of $R$. communis $L$. whole plant as well as their biological pharmacological activities. These studies have established the therapeutic potential of $R$. communis $L$. in modern medicine and about it as a possible candidate for drug discovery. The present review gives an overview of $R$ communis chemical composition and various pharmacological and biologicals activities.

Index Terms - anticancer, antimicrobial, antioxidant,
\end{abstract} Ricinus communis $\mathbf{L}$.

\section{INTRODUCTION}

Literature has it that plants are a treasure host of potential medicine. In the recent times, the importance of medicinal plants has been on the rise [2]. Consequently, plants which have been under study on medicinal purpose constitute the most evident preference in analysing the current search for restoratively powerful modern drugs such as anticancer, antimicrobial and antioxidants compounds [14]. More of the world populace is currently shifting towards the traditional medicine system due to the various side effects frequently encountered in synthetic drugs [3]. A restorative medicinal plant containing partial organic compounds with physiological activity on the human body can be represented by $\mathrm{R}$. communis L. This is a long-lived perpetual shrub within the family of Euphorbiacea and can develop to the measure of a small tree in appropriate conditions.

\section{A.Morphology}

This castor oil plant (Figure 1A) is a fast-growing, suckering perennial shrub, soft wooded small tree of up to 6

Constantine Kameti, PhD Student at Kenyatta University in Organic Chemistry, Kenya

Dr. Henry Mwangi, Lecturer, Membership in Professional Societies: Kenya Chemical Society and Royal Society of Chemistry, Kenya Dr. Margaret Ng'ang'a, Kenya meters or more, but it is not hardy in nature. Moreover, these plants are cultivated for leaf and flower colours (Figure 1B) and seeds for oil production. It can shift significantly in its growth habit and appearance [5]. The glossy leaves are 15-45 cm long, long-stalked, substitute and palmate with 5-12 deep lobes with coarsely toothed sections. The flowers are monoecious and about $40-50 \mathrm{~cm}$. long. The fruit is a three-celled thorny capsule covered by a soft spins like processes and dehisces into three 2-valved cocci (Figure 1C). The seeds vary in size and colour (Figure 1D). They are ovoid, compressed, 7-15 mm long and 3-11 mm broad. They have a very smooth testa, thin and brittle. R. communis L. seeds have a warty member called the caruncle, which is a type of elaiosome. The caruncle advances the dispersal of the seed by ants (myrmecochory) [20].

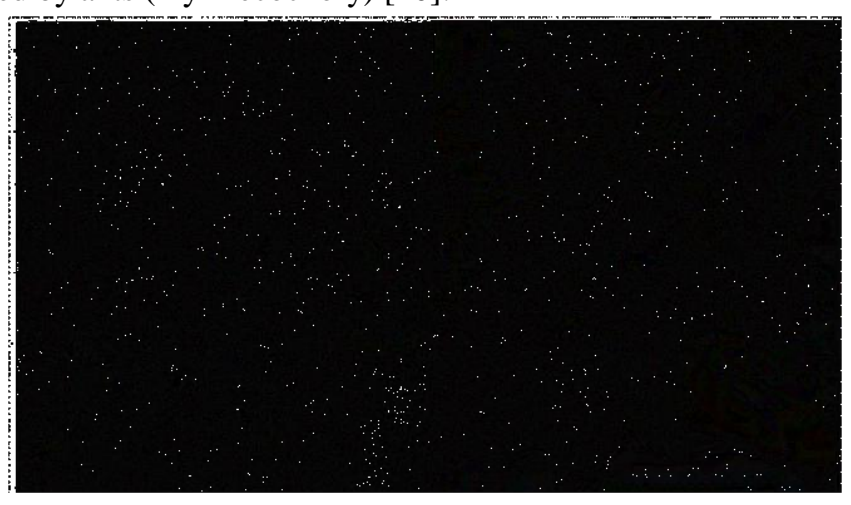

A: Shoot of the plant B: Flowers

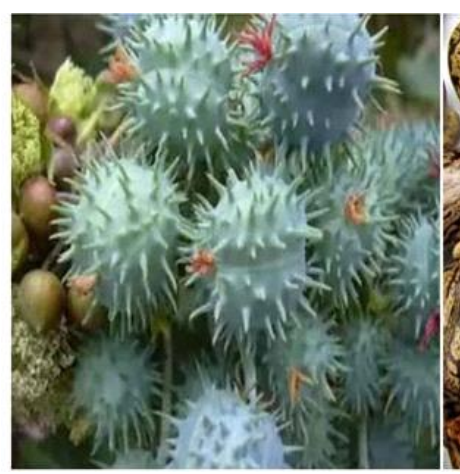

C: Fruit (Capsules)

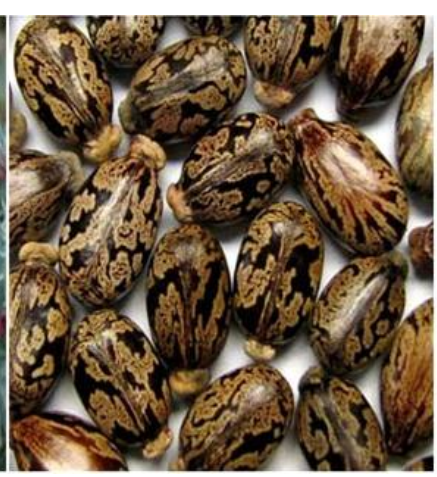

$\mathbf{D}:$ Seeds
Figure 1: Ricinus communis morphology

Source; [10]

\section{B. Habitat}

Ricinus Communis is a hardy crop which grows in a wide range of ecology. Essentially, it grows throughout the warm-temperate and tropical regions, it prospers under varieties of climate conditions that its range cannot easily be 
defined. Moreover, it is fundamentally long-day plant, yet is versatile with less respect to a wide scope of photoperiod. Nonetheless, Ricinus Communis flowers normally on both a short 12-hour and a long 18-hour day, but at 9 hours growth and development are severely hindered [19]. Ricinus Communis grows in a wide range of soils, preferably a well-drained moisture retentive soil like sandy loam. It develops well in on a rich soil and endures not less than daytime temperatures of $20^{\circ} \mathrm{C}$. It tolerates $\mathrm{pH}$ of 4.5 to 8.3 and annual temperature of 7 to $27.8{ }^{\circ} \mathrm{C}$ and annual precipitation of 20 to $429 \mathrm{~cm}$ [19]. Insufficient nitrogen results in reduced seed yields and excessive nitrogen results in extensive and heavy vegetative growth with non-significant increase in yields. The measure of nitrogen necessity relies upon the soil organic matter content. Fundamentally Ricinus Communis requires indistinguishable measure of supplements from other low-demand field crops [19]. Two varieties of this plant are known, one with a lasting rugged plant with large fruits and large red seeds which yields about $40 \%$ of oil and secondly, a much smaller annual shrub with small grey (white) seeds having brown spots and yielding $37 \%$ of oil [25].

\section{Benefits of the plant}

The castor oil obtained from the seed of the plant is still widely used traditionally and herbally as a medicine. Furthermore, the seed of the plant is used as fertilizer after extraction of oil which is roasted to destroy the toxins and used in the manufacture of animal feeds. The main utilization of the oil is to serve as a laxative and purgative [23]. Likewise, it is also used as a lubricant, lamp fuel, in the manufacture of cosmetics, fibers, soaps, printer's ink, plastics, hydraulic fluid, brake fluid, varnishes, paints, embalming fluid, textile dyes, leather finishes, adhesives, waxes, and fungicides. In Asia, the leaves are used as food for silk worms and the stalks used for fuel purpose [5].

\section{PHYTOCHEMICALS}

A preliminary phytochemical study of $R$. communis revealed the presence of disaccharide glycoside rutin, gentistic corrosive, quercetin and gallic acid in their dried leaves [17]. Flavonoids and tannins have been isolated from the leaves (Table I), [9]. The seeds contain ricin A, B, C and ricinus agglutinin [9]. Indole-3- acetic acid has been extracted from the roots [9]. The pericarp of the organic products has indicated some levels of alkaloid and ricinine [9]

Table I: Phytochemicals tested in Ricinus communis $\mathbf{L}$.

\begin{tabular}{|c|c|c|c|c|c|c|}
\hline Extracts & $\begin{array}{l}\text { Sterols and } \\
\text { Terpenoids }\end{array}$ & Tannins & Flavonoids & $\begin{array}{l}\text { Indole } \\
\text { Flavonoids }\end{array}$ & $\begin{array}{l}\text { Carbohydrates and } \\
\text { Gycosides }\end{array}$ & Saponins \\
\hline \multicolumn{7}{|c|}{ Petroleum Ether extract } \\
\hline Leaves & +++ & ++ & + & ++ & ++ & ++ \\
\hline Root & + & -- & + & + & -- & + \\
\hline Stem & ++ & -- & + & + & ++ & ++ \\
\hline Seed & ++ & -- & + & + & -- & + \\
\hline \multicolumn{7}{|c|}{ Ether extract } \\
\hline Leaves & + & -- & ++ & ++ & ++ & ++ \\
\hline Root & -- & -- & + & + & + & ++ \\
\hline Stem & -- & -- & + & ++ & ++ & + \\
\hline Seed & ++ & + & ++ & + & -- & + \\
\hline \multicolumn{7}{|c|}{ Chloroform extract } \\
\hline Leaves & + & ++ & + & + & + & + \\
\hline Root & -- & + & + & + & -- & + \\
\hline Stem & -- & -- & ++ & + & -- & + \\
\hline Seed & + & -- & + & + & ++ & + \\
\hline \multicolumn{7}{|c|}{ Methanol extract } \\
\hline Leaves & ++ & + & + & + & -- & + \\
\hline Root & ++ & + & + & + & ++ & -- \\
\hline Stem & + & + & + & + & + & + \\
\hline Seed & + & + & + & + & + & + \\
\hline \multicolumn{7}{|c|}{ Aqueous extract } \\
\hline Leaves & -- & + & + & -- & + & + \\
\hline Root & -- & -- & + & -- & + & + \\
\hline Stem & -- & -- & + & + & + & + \\
\hline Seed & + & -- & + & + & +++ & + \\
\hline
\end{tabular}

Source; [12]

Table 11: In-Vitro Cytotoxicity of Plant Extract of R. communis Linn (seed part) Against Human Cancer Cell Line

\begin{tabular}{|l|l|l|l|l|l|l|l|l|l|}
\hline Plant name & $\begin{array}{l}\text { Plant } \\
\text { Part }\end{array}$ & $\begin{array}{l}\text { Conc } \\
\mu \mathrm{g} / \mathrm{mL}\end{array}$ & $\begin{array}{l}\text { SF } \\
295\end{array}$ & $\begin{array}{l}\text { Colon } \\
502713\end{array}$ & $\begin{array}{l}\text { Colon } \\
\text { Colo205 }\end{array}$ & $\begin{array}{l}\text { Liver } \\
\text { Hep-2 }\end{array}$ & $\begin{array}{l}\text { Lung } \\
\text { A-549 }\end{array}$ & $\begin{array}{l}\text { Ovary } \\
\text { Ovcar-5 }\end{array}$ & $\begin{array}{l}\text { ProstrateP } \\
\text { C-5 }\end{array}$ \\
\hline
\end{tabular}




\begin{tabular}{|c|c|c|c|c|c|c|c|c|c|}
\hline \multicolumn{10}{|c|}{$\%$ Growth Inhibition } \\
\hline $\begin{array}{l}\text { Ricinus } \\
\text { communs }\end{array}$ & Seed & 100 & - & 41 & - & - & 11 & 12 & 14 \\
\hline
\end{tabular}

(-) means that extract was not evaluated with particular human cancer cell line Source; [4]

Table III: In-Vitro Cytotoxicity of Plant Extract of $R$. communis Linn (stem part) Against Human Cancer Cell Line

\begin{tabular}{|l|l|l|l|l|l|l|l|l|l|}
\hline Plant name & $\begin{array}{l}\text { Plant } \\
\text { Part }\end{array}$ & $\begin{array}{l}\text { Conc } \\
\mu \mathrm{g} / \mathrm{mL}\end{array}$ & $\begin{array}{l}\text { He } \\
\mathrm{p}-2\end{array}$ & $\begin{array}{l}\text { Breast } \\
\mathrm{T}-47 \mathrm{D}\end{array}$ & $\begin{array}{l}\text { Colon } \\
\text { HT-29 }\end{array}$ & $\begin{array}{l}\text { Prostrate } \\
\text { PC-3 }\end{array}$ & $\begin{array}{l}\text { SW- } \\
620\end{array}$ & $\begin{array}{l}\text { Colo } \\
\text { SiHa }\end{array}$ & $\begin{array}{l}\text { Ovary } \\
\text { OVCAR-5 }\end{array}$ \\
\hline \% Growth Inhibition \\
\hline $\begin{array}{l}\text { Ricinus } \\
\text { communs }\end{array}$
\end{tabular}

(-) means that extract was not evaluated with particular human cancer cell line

Source; [4]

Table V: Antioxidant profile of extracts of $R$. communis different parts, extracted by different extraction methods

\begin{tabular}{|c|c|c|c|c|c|c|c|}
\hline $\begin{array}{l}\text { S/ } \\
\text { No }\end{array}$ & Method & $\begin{array}{l}\text { Plant } \\
\text { parts }\end{array}$ & $\begin{array}{l}\text { TPC } \\
(\mathrm{mg} / 100\end{array}$ & $\begin{array}{l}\text { TFC } \\
(\mathrm{mg} / 100 \\
\text { g) }\end{array}$ & $\begin{array}{l}\text { DPPH } \\
\text { inhibition } \\
(\%)(0.1 \mathrm{mg} / \mathrm{mL})\end{array}$ & $\begin{array}{l}\text { Linoleic } \\
\text { acid inhibition } \\
(\%)\end{array}$ & $\begin{array}{l}\text { R. Power } \\
(1 \\
\text { mg/mL) } \\
\text { (OD) }\end{array}$ \\
\hline 1 & Shaking $^{\mathrm{C}}$ & Seed $^{b}$ & $122 \pm 3$ & $15 \pm 1$ & $7.25 \pm 0.3$ & $43.56 \pm 0.3$ & $\begin{array}{ll} & 0.481 \\
0.8\end{array}$ \\
\hline 2 & & Stem $^{d}$ & $24 \pm 1$ & $6 \pm 0.2$ & $20 \pm 0.2$ & $12.46 \pm 0.7$ & $\begin{array}{c}0.278 \pm \\
0.3\end{array}$ \\
\hline 3 & & a & $165 \pm 1.5$ & $71 \pm 1$ & $7.54 \pm 0.2$ & $57.38 \pm 0.2$ & ${ }_{0.6} \begin{array}{ll}0.578 & \pm\end{array}$ \\
\hline 4 & & Fruit $^{\mathrm{c}}$ & $94 \pm 2$ & $68 \pm 2$ & $5.14 \pm 0.3$ & $35.69 \pm 0.4$ & $\begin{array}{ll}0.396 & \pm \\
0.1 & \end{array}$ \\
\hline 5 & & $\operatorname{Root}^{\mathrm{e}}$ & $16 \pm 1$ & $4 \pm 0.1$ & $6.58 \pm 0.8$ & $10.84 \pm 0.9$ & ${ }_{0.7}^{0.209} \pm$ \\
\hline 6 & Sonication $^{\mathbf{A}}$ & Seed $^{\mathrm{a}}$ & $361 \pm 2$ & $\begin{array}{cc}171 \quad \pm \\
2.8\end{array}$ & $8.8 \pm 0.6$ & $87.28 \pm 0.1$ & $\begin{array}{ll} & 0.854 \\
0.3 & \pm\end{array}$ \\
\hline 7 & & Stem $^{c}$ & $11 \pm 0.3$ & $4 \pm 0.6$ & $6.2 \pm 0.9$ & $8.14 \pm 0.7$ & ${ }_{0.2}^{0.184} \pm$ \\
\hline 8 & & b & $58 \pm 1$ & $32 \pm 1.2$ & $10.45 \pm 0.7$ & $20.64 \pm 0.3$ & $\begin{array}{ll} & 0.356 \\
0.8\end{array}$ \\
\hline 9 & & Fruit $^{b}$ & $64 \pm 2$ & $46 \pm 1.2$ & $5.67 \pm 0.1$ & $23.54 \pm 0.6$ & $\begin{array}{ll}0.379 & \pm \\
0.3 & \end{array}$ \\
\hline 10 & & $\operatorname{Root}^{c}$ & $12 \pm 0.5$ & $2.8 \pm 0.6$ & $13.29 \pm 0.7$ & $11.39 \pm 0.2$ & $\begin{array}{cc}0.234 & \pm \\
0.9 & \end{array}$ \\
\hline 11 & Soxhlet $^{B}$ & Seed $^{\mathrm{a}}$ & $149 \pm 1.5$ & $94 \pm 0.4$ & $7.42 \pm 0.5$ & $48.19 \pm 0.3$ & $\begin{array}{cc}0.523 & \pm \\
0.7 & \end{array}$ \\
\hline 12 & & Stem $^{c}$ & $5 \pm 0.1$ & $16 \pm 0.1$ & $14.33 \pm 0.9$ & $6.63 \pm 0.5$ & $\begin{array}{ll} & 0.194 \\
0.4\end{array}$ \\
\hline 13 & & b Leave & $31 \pm 1$ & $39 \pm 0.6$ & $13.99 \pm 0.4$ & $26.32 \pm 0.6$ & $\begin{array}{ll}0.376 & \pm \\
0.6 & \end{array}$ \\
\hline 14 & & Fruit $^{b}$ & $23 \pm 0.5$ & $34 \pm 0.3$ & $6.9 \pm 0.8$ & $21.21 \pm 0.9$ & ${ }_{0.2}^{0.362} \pm$ \\
\hline 15 & & $\operatorname{Root}^{c}$ & $9 \pm 0.9$ & $2 \pm 0.1$ & $8.24 \pm 0.6$ & $7.23 \pm 0.3$ & $\begin{array}{cc}0.231 & \pm \\
0.8 & \end{array}$ \\
\hline
\end{tabular}

The values are the mean \pm SD of triplicate experiments. Capital letters in superscripts are representing significant different among extraction methods $(P<0.05)$ and small letter in superscripts are representing significance difference $(P<0.05)$ in activity within plant parts for individual extraction methods

Source; [1]

Studies have concluded that some of the bioactive compounds from medicinal plants are toxic to our normal system [26] therefore safety is critical in the development of novel drugs [11]. In the case of $R$. communis, cytotoxicity effect of hexane, dichloromethane, acetone and methanol 
leaf extracts at concentration ranging from 100-500 g/mL has been done and analysed by several researchers on Human Caucasian skin fibroblast (Bud-8) cell line using MTT assay [26]. The findings concluded that all crude extracts were toxic to Bud-8 cell line at the higher concentration of $500 \mathrm{~g} / \mathrm{mL}$. However, at the lower concentrations $(100 \mathrm{~g} / \mathrm{mL})$, hexane and dichloromethane extracts had more than $90 \%$ cell viability after 24 and 48 hours of exposure. Acetone and methanol extracts had less than $90 \%$ cell viability. Cell viability decreased with the increase in concentrations of plant extracts. Higher concentrations of $R$. communis extracts were observed to be toxic on Bud-8 cell line.

Reference [17] reported the toxic effect of ricin isolated from the seeds of $R$. communis. Ricin kills the cells by disrupting protein synthesis in the cells. Roots and leaves extracts are known to contain similar constituents at varying concentrations [4], [7]. Ethanolic extract of seed part of Ricinus communis have been found to be active against Colon 502713, A-549, OVCAR-5 and PC-5 human cancer cell lines. The cytotoxic activity was $41 \%, 11 \%, 12 \%$ and $14 \%$ respectively (Table II). The stem part of $R$. communis showed $9 \%, 31 \%$ and $40 \%$ activity against Hep-2, HT-29 and $\mathrm{SiHa}$ cell lines at $100 \mu \mathrm{g} / \mathrm{mL}$ concentration ethanol extract (Table III). Reference [26] reported high $\mathrm{LC}_{50}$ on methanol extract, followed by hexane, dichloromethane and acetone in $R$. communis leaf extracts on Bud-8 cell line (Table IV). Reference [11] also reported low toxic effect of methanol extracts on MAGI CCR5+ cell lines after 24 hours.

\section{B. Antioxidant activity}

\section{Total phenolic and flavonoid content}

$R$. communis has shown promising antioxidant activity through the presence of total phenolic contents (TPC) and total flavonoid contents (TFC) of different parts of the plant (Table V) [1].

\section{DPPH method}

The DPPH radical scavenging assay is an easy rapid and sensitive method for the antioxidant screening of plant extracts [18] and the assay is known to give reliable information concerning the antioxidant ability of the tested compounds. A freshly prepared DPPH solution exhibits a deep blue colour in the medium of methanol. Antioxidant molecules quench DPPH free radicals (by providing hydrogen atoms or by electron donation, via a free radical attack on the DPPH molecule) and convert them to colourless (2, 2-diphenyl-1-hydrazine or a substituted analogous hydrazine), result in a decrease in absorbance at $517 \mathrm{~nm}$. The more rapidly the absorbance decreases, the higher the antioxidant activity of the extract [18]. Antioxidant activity of different $R$. communis extracts have been performed by using different extraction methods (Table 5).

Table IV: The $\mathrm{LC}_{50}$ of $R$. communis extracts on BUD-8 cell lines after 24 and 48 hours of exposure.

\begin{tabular}{|l|l|l|}
\hline $\begin{array}{l}\text { Extracts } \\
48 \text { hours }\end{array}$ & $\mathrm{LC}_{50}(\mu \mathrm{g} / \mathrm{mL})$ & 24 hours \\
\hline Hexane & 629.3 & 495 \\
\hline Dichloromethane & 573.6 & 467 \\
\hline Acetone & 544.5 & 471 \\
\hline Methanol & 784 & 387 \\
\hline
\end{tabular}

Source; [26]

Free Radical Scavenging Activity

The free radical scavenging activity a method used to test for antioxidant activity of plant extracts is done by preparing $0.002 \%$ DPPH solution in methanol. Gallic acid is taken as the reference standard [18]. Different concentrations of the extract (100, 200 and $500 \mu \mathrm{g} / \mathrm{mL})$ and standard drug (1 and $2.5 \mu \mathrm{g} / \mathrm{mL})$ are prepared using methanol. $1 \mathrm{~mL}$ of $0.002 \%$ DPPH solution is mixed with $1 \mathrm{~mL}$ of all the concentrations of both extract and standard separately. These mixtures are kept in dark for about 30 minutes and the optical density measured at $517 \mathrm{~nm}$. DPPH $(0.002 \%)$ and methanol mixture is the blank. Finally the percentage inhibition of the DPPH activity is calculated using equation (1) below [18].

$$
\operatorname{Inhibition}(\%)=\frac{\text { Absorbance }_{\text {control- }} \text { Absorbance }_{\text {sample }}}{\text { Absorbance }_{\text {control }}} \times 100
$$

The antioxidant activity of the extract is expressed as $\mathrm{IC}_{50}$ and compared with standard. The $\mathrm{IC}_{50}$ value is the concentration (in $\mu \mathrm{g} / \mathrm{mL}$ ) of extracts that scavenges the

DPPH radicals by 50\% (Table VI).

Antioxidant activity in linoleic acid system

The rate of inhibition of peroxidation of linoleic acid system has been determined procedurally [1]. An aliquot of; 5 $\mathrm{mg}$ of the extract, $0.13 \mathrm{~mL}$ of linoleic acid, $10 \mathrm{~mL}$ of $99.8 \%$ of ethanol and $0.2 \mathrm{M}$ of sodium phosphate buffer $(\mathrm{PH} 7.0)$ are mixed with $25 \mathrm{~mL}$ of disitilled water and incubated at $40{ }^{\circ} \mathrm{C}$. The thiocyanate method is applied to measure the degree of oxidation. The percentage inhibition of linoleic acid is then calculated as per equation (2) given below.

$$
\operatorname{Inhibition}(\%)=100-\frac{A_{s, 175 h}}{A_{o, 175 h}} \times 100
$$

Where;

$\mathrm{A}_{\mathrm{s}, 175 \mathrm{~h}}$ is the absorbance value at $175 \mathrm{~h}$ of the sample

$\mathrm{A}_{0,175 \mathrm{~h}}$ is the absorbance value at $175 \mathrm{~h}$ of the control

\section{Reducing power assay}

Different concentrations of the extract (100, 200 and 500 $\mu \mathrm{g} / \mathrm{mL})$ and standard drug (1.0 and $2.5 \mu \mathrm{g} / \mathrm{mL})$ are prepared using distilled water. $1 \%$ potassium ferricyanide, $10 \%$ trichloro acetic acid, $0.1 \%$ ferric chloride and $0.2 \mathrm{M}$ phosphate buffer are prepared using distilled water. Gallic acid is taken as the reference standard. Then $1 \mathrm{~mL}$ of each concentration of both extract and standard are taken separately and mixed with $1 \mathrm{~mL}$ of $0.2 \mathrm{M}$ phosphate buffer ( $\mathrm{PH}$ 6.6) and $1 \mathrm{~mL}$ of potassium ferricyanide. All these samples are incubated at $50{ }^{\circ} \mathrm{C}$ for 20 minutes. Addition of 1 $\mathrm{mL}$ of $10 \%$ trichloroacetic acid is done and centrifuged at $2000 \mathrm{rpm}$ for 10 minutes. The upper layer $(2.5 \mathrm{~mL})$ is separated and distilled water $(2.5 \mathrm{~mL})$ plus $0.5 \mathrm{~mL}$ of freshly prepared ferric chloride added. Absorbance at $700 \mathrm{~nm}$ is done 


\section{(Table V) [21].}

In this assay, the yellow colour of the test solution changes to various shades of green and blue depending on the reducing power of each compound. Presence of reducers causes the conversion of the $\mathrm{Fe}^{3+} /$ ferric cyanide complex used in this method to the ferrous form. By measuring the formation of Pearl's Prussian blue at $700 \mathrm{~nm}$, it is possible to determine the concentration of $\mathrm{Fe}^{2+}$ ion [6], [18]. The reducing power of the extract increases with increase in concentration, of ethanolic leaf extract (Table VII).

Table VI: DPPH radical scavenging activity of ethanolic leaf extract of Ricinus communis

\begin{tabular}{|l|l|l|l|}
\hline $\begin{array}{l}\text { Tested } \\
\text { Material }\end{array}$ & $\begin{array}{l}\text { Concentration } \\
(\boldsymbol{\mu g} / \mathbf{m L})\end{array}$ & $\begin{array}{l}\boldsymbol{\%} \text { Inhibition } \\
\mathbf{\pm S E M}\end{array}$ & $\begin{array}{l}(\boldsymbol{\mu} \mathbf{g} / \mathbf{m L}) \\
\mathbf{I C}_{\mathbf{5 0}}\end{array}$ \\
\hline Ethanolic & 100 & $60.67 \pm 0.01$ & 37.32 \\
leaf & 200 & $63.54 \pm 0.023$ & - \\
extract & 500 & $79.08 \pm 0.002$ & - \\
Gallic acid & 1.0 & $56.19 \pm 0.0125$ & 0.81 \\
& 2.5 & $93.4 \pm 0.0007$ & - \\
\hline
\end{tabular}

Source; [18]

Table VII: Effect of ethanolic leaf extract of Ricinus communis on Reducing power assay

\begin{tabular}{|l|l|l|}
\hline $\begin{array}{l}\text { Tested } \\
\text { Material }\end{array}$ & $\begin{array}{l}\text { Concentration } \\
(\boldsymbol{\mu g} / \mathbf{m L})\end{array}$ & $\begin{array}{l}\text { Absorbance } \\
\mathbf{\pm S E M}\end{array}$ \\
\hline Ethanolic leaf & 100 & $0.295 \pm 0.026$ \\
extract of $R$. & 200 & $0.491 \pm 0.020$ \\
Communis & 500 & $0.947 \pm 0.009$ \\
& 1.0 & $0.471 \pm 0.011$ \\
Gallic acid & 2.5 & $0.765 \pm 0.013$ \\
\hline
\end{tabular}

Source; [18]

\section{Antimicrobial activity}

Different bacterial strains have been used to test bacterial activity of $R$. communis root extracts [13], [27]. Hexane and methanol extracts $(200 \mathrm{mg} / \mathrm{mL})$ of roots of Ricinus communis have shown good activity against microbes (Table VIII) while aqueous extracts have exhibited no antimicrobial activity against any of the microbes [15].

\section{G. Antidiabetic activity}

According to [2] ethanol root extracts of R. communis possess significant effects on fasting blood glucose, absolute lipid profile, liver and kidney functions and no significant difference on alkaline phosphatase, serum bilirubin, creatinine, serum glutamate oxaloacetate transaminases, serum glutamate pyruvate transaminases and total protein which is observed even after the administration of the extract at a dose of $10 \mathrm{~g} / \mathrm{kg}$ body weight [25]. The ethanolic root extract has been found to reduce glucose level in normal and in diabetic rats in dose dependant way up to $500 \mathrm{mg} / \mathrm{kg}$ body weight [9]. The decrease in noticeable activity at higher doses could be attributed to reduction or no effect of the phytochemicals present in the extract at higher levels [9]. Otherwise failure to produce hypoglycemic effect due to interfering compounds in the root extracts. Studies as in [9] indicate that higher doses of the extract may contain higher levels of hypoglycemic compounds. Hence, $500 \mathrm{mg} / \mathrm{kg}$ body weight has been found to be the effective dose of $R$. communis root extract on fasting blood glucose (FBG) of normal as well as diabetic animals [9].

\section{H. Antihistaminic activity}

R. communis L., ethanolic root extract has been found to have antihistaminic effect at variable doses of 100, 125, and 150 $\mathrm{mg} / \mathrm{kg}$ body weight. This was observed upon insertion into the body intraperitoneally by utilizing clonidine initiated catalepsy in mice [8], [25].

\section{Antiasthmatic activity}

Ethanol root extract of R. communis is potentially viable in the treatment of asthma since it has antiallergic and mast cell stabilizing activity. Saponins present in the root extract have strong cell stabilizing effect while the flavonoids contain smooth muscle relaxant and bronchodilator activity; proofing in vivo antiallergic activity [25]. The $R$. communis ethanolic root is known to possess antiasthmatic activity due to the flavonoids or saponins present [25].

\section{J. Antinociceptive activity}

The methanolic leaves extract of $R$. communis possesses significant antinociceptive activity towards acetic acid induced writhing test, formalin induced paw licking and tail immersion strategies in mice. The antinociceptive activity implicated is due to the presence of preliminary phytoconstituents namely saponins, steroids and alkaloids, stigmasterol, Y-sitosterol and fucosterol [16], [25].

\section{K. Wound healing activity}

The $R$. communis have wound healing activity because of the dynamic constituent of castor oil which produce antioxidant activity and restrain lipid per oxidation [8]. Those agents that inhibit lipid per oxidation are known to increase the viability of collagen fibrils by strengthening the collagen fibers, hastening the circulation, checking the cell damage and by boosting the DNA synthesis [8], [25]. Castor oil is believed to contain tannins, flavonoids, triterpenoids and sesquiterpene which play a major role in the wound healing processes due to the astringent and antimicrobial property [25]. Studies have shown that, $10 \% \mathrm{w} / \mathrm{w}$ Castor oil ointment possesses better wound-healing property [8], [25].

\section{Larvicidal activity}

The aqueous leaf extract of $R$. communis have appropriate Larvicidal activity against Anopheles arabiensis, Callosobruchus chinensis and Culex Quinquefasciatus mosquitoes [25]. Immunomodulatory agents generally increase the immune responsiveness of the human body against pathogens by enacting the non-specific immune system. The phagocytosis is the engulfment of microorganism by leucocytes. In last the phagocytosis is the intracellular killing of microorganisms by the neutrophils. The presence of tannins in the leaves of $R$. communis significantly increases the phagocytic function of human neutrophils leading to a possible immunomodulatory effect [25]. 
In Vitro Anticancer, Antimicrobial and Antioxidant Screening Of Compounds from Ricinus Communis Linn: A Review

\begin{tabular}{|l|l|l|l|l|l|}
\hline \multicolumn{5}{|c|}{ Pathogens Diameter of Zone of Inhibition(mm) \pm SD } \\
\hline Pathogens & $\begin{array}{l}\text { Chloramphenicol } \\
(1 \mathrm{mg} / \mathrm{mL})\end{array}$ & $\mathrm{H}$ & $\mathrm{P}$ & $\mathrm{A}$ & $\mathrm{M}$ \\
\hline Bacillus subtilis & $17.0 \pm 1.7$ & $5.0 \pm 0.7$ & $6.0 \pm 0.6$ & $\mathrm{NA}$ & $7.0 \pm 0.56$ (in single line) \\
\hline $\begin{array}{l}\text { E. coli } \\
\text { Proteus vulgaris }\end{array}$ & $16.0 \pm 1.2$ & $6.0 \pm 0.7$ & $5.0 \pm 0.5$ & $\mathrm{NA}$ & $18 \pm 0.52$ (in single line) \\
\hline $\begin{array}{l}\text { Salmonella } \\
\text { typhimurtium }\end{array}$ & $15.0 \pm 1.2$ & $7.0 \pm 1.3$ & $5.0 \pm 0.4$ & $\mathrm{NA}$ & $8.0 \pm 0.45$ (in single line) \\
\hline $\begin{array}{l}\text { Pseudomonas } \\
\text { aeruginosa }\end{array}$ & $12 \pm 1.4$ & $6.0 \pm 1.8$ & $5.0 \pm 0.5$ & $\mathrm{NA}$ & $9.0 \pm 0.56$ (in single line) \\
\hline $\begin{array}{l}\text { Staphylococcus } \\
\text { aerus }\end{array}$ & $12 \pm 1.4$ & $7.0 \pm 1.0$ & $8.0 \pm 0.6$ & $\mathrm{NA}$ & $8.0 \pm 0.56$ (in single line) \\
\hline
\end{tabular}

Hexane: P- Petroleum ether: A- Aqueous: M- Methanol (each $200 \mathrm{mg} / \mathrm{mL}$ ): NA - No activity

Source; [27]

\section{M.Anti-implantation activity}

The ether soluble portion of the methanol extract of $R$. communis var. minor have shown to possess anti-implantation, anti-conceptive and estrogenic activity in adult female rats and rabbits when administered subcutaneously at a dose up to $1.2 \mathrm{~g} / \mathrm{kg}$ body weight and 600 $\mathrm{mg} / \mathrm{kg}$ body weight, in divided doses, respectively [8].

\section{N. Insecticidal activity}

The insecticidal importances of the castor oil in controlling the termites which damage the wood of Mangifera indica and Pinus longifolia have been analysed. Comparative trials indicated the order of insecticidal activity as: BHC (Benzene hexachloride) $>$ castor oil + castor cake $(1: 1)>$ castor oil > castor leaves $>$ castor cake $>$ neem oil $>$ neem leaves [8].

\section{O. Larvicidal and molluscicidal activity}

The leaf extract of $R$. communis possess molluscicidal activity against Lymnaea acuminata and the seed extracts have shown better molluscicidal activity than the leaf extracts against $S$. frugiperda because of the active ingredients like castor oil and ricinine [8]. The aqueous leaves extracts of $R$. communis possess suitable larvicidal activity against Anopheles arabiensis, Callosobruchus chinensis and Culex quinque fasciatus mosquitoes, with a mortality rate of approximately $100 \%$ [2], [8]. The $R$. communis seed extract has exhibited a lethal concentration among various larval species as follows: Culex quinque fasciatus $(7.10 \mu \mathrm{g} / \mathrm{mL})$ $>$ Anopheles stephensi $(11.64 \mu \mathrm{g} / \mathrm{mL})>$ Anopheles albopictus $(16.84 \mu \mathrm{g} / \mathrm{mL})[2]$.

\section{P. Bone regeneration activity}

Castor oil has been used as herbal and folkloric medicine in the treatment of bone deformities, acute osteomyelitis, articular pains, and afflicted limbs [2]. Studies on Ricinus communis polyurethane (RCP) indicate its biocompatibility and ability to stimulate the bone regeneration. Research show that RCP blended with calcium carbonate or calcium phosphate could promote matrix mineralization and are biocompatible materials [24]. Fusing alkaline phosphatase to RCP with subsequent incubation in synthetic body fluid could improve the biological properties of the RCP [8]. The advantage seen in RCP as compared to demineralized bone is that the former has a slower reabsorption process [8].

\section{Q. Central analgesic activity}

The crude root bark extract of $R$. communis possesses central analgesic activity in tail flick response model to radiant heat at a dose of $250 \mathrm{mg} / \mathrm{kg}$ body weight. The ethanol pericarp fruit extract of $R$. communis possesses typical central nervous system stimulant and neuroleptic effects [8]. The stimulant effects, such as exophthamus, hyperreactivity, memory improvement, and clonic seizures, appear to be due to the presence of alkaloid ricinine [2]. The main toxic compound of the extract also seems to be ricinine, because animals that died after administration of the extract or ricinine gave comparable indications: they all died after the occurrence of clonic seizures followed by evident breathing arrest. Similarly, compounds other than ricinine may also be responsible for the neuroleptic-like effects of the extract, because ricinine is not known to show a reduction of locomotor activity or catalepsy in the mice [8].

\section{R. Anti-inflammatory activity}

Anti-inflammatory activity has been reported on the leaves and root extract of $R$. communis in rats [8]. The 250 and 500 $\mathrm{mg} / \mathrm{kg}$ dose of $R$. communis methanol leaves extract possess protective effect in the prevention of cellular events during edema formation and in all the stages of acute inflammation [22]. The antiinflammatory potential of the $R$. communis methanolic extract is due to the presence of flavonoids against carragennan-induced paw edema in rats [16].

\section{S. Lipolytic activity}

The ricin produces the lipolytic activity by using the various substrates: such as an analogue of triacylglycerol, BAL-TC, a chromogenic substrate p-NP esters of a

liphatic short to medium chain acids, and monomolecular films of a pure natural diacylglycerol, DC10 in emulsion and in a Membrane-like model [16]. It reveals that ricin from $R$. communis act as a lipase and has the capability of hydrolyzing different lipid classes. The action of ricin on membrane phospholipids could occur through a phospholipase activity which is very often as a minor activity of lipases [8].

\section{T. Hepatoprotective activity}

Hepatoprotective effect studies show that, ethanol leaves extract of $R$. communis at different doses, the presence of 
flavonoids and tannins exhibit an inhibitory effect on the activities of serum transaminases, liver lipid peroxidation level and the activities of acid and alkaline phosphatase in liver initiated by carbon tetrachloride [8]. N-demethyl ricinine have shown anticholestatic and hepatoprotective potential in paracetamol-induced hepatic damage [8]. The whole leaves of Ricinus communis have exhibited protective effect towards liver necrosis in addition fatty changes induced by carbon tetrachloride, while the glycoside and cold aqueous extract give protection against liver necrosis and fatty changes respectively [16].

\section{CYTOTOXIC EFFECT}

Studies on Cytotoxic effect of leaves extract of $R$. communis on SK-MEL-28 human melanoma cells have been reported [7]. The leaves have shown the presence of cytotoxic phytochemicals, which induces apoptosis via translocation of phosphatidyl serine to the external surface of cell membrane and loss of mitochondrial potential. These compounds include three monoterpenoids: 1, 8-cineole, camphor and $\alpha$-pinene and a sesquiterpenoid: $\beta$-caryophyllene [8].

\section{CONCLUSION}

In vitro anticancer, antimicrobial and antioxidant efficiency of the different parts of $R$. communis carried out in this review paper, reveal that the plant is a viable source of novel medicine to life threatening diseases globally. The phytochemical and medicinal properties of $R$. communis are attributed to its wide biological activity due to the presence of its enormous scope of bioactive compounds. It is then justifiable through this review that both the crude form of the plant and its isolated compounds are potential for drug discovery either in synergy or single formulation therapy in future prospects. Future studies on, in vitro and in vivo of the bioactive and isolated pure compounds can be used to investigate the mode of action of these compounds hence boosting the health sector. Further research on $R$. communis on therapeutic drug delivery mechanism will be significant by using the nanotechnology to deal with the emerging trend of drug resistance, presence of superbugs and above all cancer therapy.

\section{ACKNOWLEDGMENT}

The authors sincerely thank Prof. Swaleh Sauda Head of Chemistry Department, Kenyatta University for her tireless support during the writing of this manuscript.

\section{REFERENCES}

[1]. Abbas, M., Abid, A., Muhammad, A., Asia A., Zahed, M., Imtiaz, M. T. and Munawar, I. (2018). Mutagenicity, cytotoxic and antioxidant activities of Ricinus communis different parts. Chemistry Central Journal. Research Article.

[2]. Abdul, W. M., Nahid, H. H., Jamal, S. M. S., Saleh, M. A., Meshaal, J. S., Saleh, A. K., Kulvinder, S. S. and Roop, S. B. (2018). Therapeutic role of Ricinus communis $\mathrm{L}$. and its bioactive compounds in disease prevention and treatment. Asian Pacific Journal of Tropical Medicine, 11:177-185.

[3]. Cherish, I. A. and Omodele, I. (2014). Whole plant screenings for flavanoids and tannins contents in Castor plant (Ricinus communis L.) and evaluation of their biological activities. International Journal of their Biological Activities, 2: 68-76.
[4]. Ekta, P. and Gupta, D. K. (2014). In Vitro study of extracts of Ricinus communis Linn on human cancer cell lines. Journal of Medical Sciences and Public Health, 2: 15-20.

[5]. Jena, J. and Gupta, A. (2012). Ricinus communis linn: A phytopharmacological review. International Journal of Pharmacy and Pharmaceutical Sciences, 4: 25-29.

[6]. Kurutas, E. B. (2015). The importance of antioxidants which play the role in cellular response against oxidative/nitrosative stress. Nutritional Journal, 15: 71.

[7]. Majumder, M., Debnath, S. and Gajbhiye, R. L. (2019). Ricinus communis L. fruit extract inhibits migration/invasion, induces apoptosis in breast cancer cells and arrests tumor progression in vivo. Science Report, 9: 14493.

[8]. Manoj, k. (2017). A Review on Phytochemical Constituents and Pharmacological.International Journal of Pharmacognosy and Phytochemical Research, 9: 466-472.

[9]. Manpreet, R., Hitesh, D., Bharat, P. and Shivani, S. (2012). Ricinus communis L. A Review. International Journal of Pharmacy Technology Research, 4: 1706-1711.

[10]. Marwat, S. K., Rehman, F. and Khan, E. A. (2017). Review-Ricinus communis-Ethnomedicinal uses and pharmacological activities. Pakistan Journal of Pharmaceutical Sciences, 30: 1815-1827.

[11]. Morobe, I. C., Mthethwa, N. S. and Bisi-Johnson, M. A. (2012). "Cytotoxic effects and safety profiles of extracts of active medicinal plants from South Africa," Journal of Microbiology Research, 2: 176-182.

[12]. More, P. and Pandhure, N. (2014). Phytochemical Analysis and Antibacterial Activity in Ricinus Communis L. Gulab Rathod. 50 - 51.

[13]. Mujeeb, F., Bajpai, P. and Pathak, N. (2014). Phytochemical evaluation, antimicrobial activity, and determination of bioactive components from leaves of Aegle marmelos. Biomedical research international, 497606.

[14]. Onyango, A., O. (2016). An ethnobotanical, phytochemical, toxicity and efficacy study of selected antiblue-Tick (Boophilu decoloratus) for herbal remedies cattle of Suba sub-county, Kenya. Published thesis. Nairobi: kenyatta University.

[15]. Rabia, N. and Asghari, B. (2012): Antimicrobial potential of Ricinus communis leaf extracts in different solvents against pathogenic bacterial and fungal strains. Asian Pacific Journal of Tropical Biomedicine, 2: 944-947.

[16]. Ram Naresh, C., Asish, B., Kalyani, P., and Krishnamachary, K (2018). Evaluation of in vivo hepatoprotective activity of ethanolic extracts of roots of Ricinus communis (EE-R-RC) against $\mathrm{CCL}_{4}$ induced rat model. Panacea Journal of Pharmacy and Pharmaceutical Sciences, 7: 83-98.

[17]. Rana, M., Dhamija, H., Prashar, B. and Sharma, S. (2012).“Ricinus communis L.—a review," International Journal of PharmTech Research, 4: 1706-1711.

[18]. Ravishankar, K. and Indira, N. (2012). Antioxidant Activity of Ethanolic Extract of Ricinus communis Leaf . Biomedical and Pharmacology Journal, 5: 179-183.

[19]. Salihu, B., Gana, A. K. and Apuyor, B.O. (2014). Castor oil plant (Ricinus communis L.): Botany, ecology and uses. International Journal of Science and Research, 3. 1333-1341.

[20]. Sasidharan, R. and Venkatesan, R. (2019); Seed Elaiosome Mediates Dispersal by Ants and Impacts Germination in Ricinus communis Frontiers in Ecology and Evolution, 7: 246.

[21]. Seyed, H., H. and Mohammadamin, D. (2017). Review of cancer from perspective of molecular. Journal of Cancer Research and Practice, 4:127-129.

[22]. Shamim. (2019). Bed Anjeer (Ricinus communis Linn.) pharmacologicalactions, therapeuticuses and Phytochemistry: A review. The Pharma Innovation Journal, 8: 10-15

[23]. Shmi, R., Pathak, D. and Kumar, R. (2019). Effect of Ricinus communis L. on Microorganisms: Advantages and Disadvantages. International Journal of Current Microbiology and Applied Sciences, 8: 878-884.

[24]. Sousa, T. P. T., Costa, M. S. T., Guilherme, R. O., Wilson, H., L. A., Silveira, E. M. V., Tavano, O. M., Aroldo G. Catanzaro-Guimarães, Sérgio, A. and Kinoshita, A. (2018). Polyurethane derived from Ricinus Communis as graft for bone defect treatments. Polímeros, 28: 246-255.

[25].Suvarna, C., Sriya, P., Arshad, M. and Pavan , K. (2018); A Review on Phytochemical and Pharmacological Properties of Ricinus communis. International Journal of Pharma Research and Health Sciences, 6: 2651-2655.

[26]. Vhutshilo, N. and Peter, M. (2014). In Vitro Assessment of Cytotoxicity, Antioxidant, and Anti-Inflammatory Activities of Ricinus Communis (Euphorbiaceae) Leaf Extracts. Research Article.

[27].Naz, R. and Bano, A. (2012). Antimicrobial potential of Ricinus communis leaf extracts in different solvents against pathogenic bacterial and fungal strains. Asian Pacific journal of tropical biomedicine, 2: 944-947. 
First author

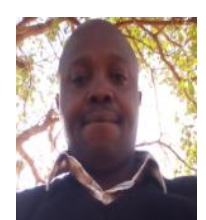

Name: Constantine Kameti

Educational Qualification

2017-to date: PhD Student at Kenyatta

University in Organic Chemistry.

2009-2013- Masters of Science (Analytical Chemistry),

Kenyatta University.

1994-1998: Bachelor of Education (Science), Second class honors, Upper division, Kenyatta University.

Seminars/workshops attended:

Jan- July 2016;

1. Research Methodology, Kenyatta University

2. Scientific Communication and Ethics, Kenyatta University

3. Statistical Data analysis, Kenyatta University

4. Project management, Kenyatta University

5. Scientific Communication and Entrepreneurship, Kenyatta University

Sep.2017: Natural Products Research Network for Eastern and Central Africa (NAPRECA, Kenya), held at University of Nairobi.

Current Research Work/Publication:

1. In vitro Anticancer, Antimicrobial and Antioxidant screening of Compounds from Ricinus communis linn: A Review

2. Anticancer, Antimicrobial and Antioxidant screening of compounds from Aspilia Aspilia mossambicensis O., Ricinnus communis L., Moringa oleifera L. and Ipomoea batatas L medicinal plants used in makueni county, kenya

Second author

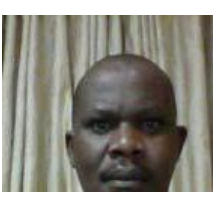

Name: Henry Mwangi

Position: Lecturer

Membership in Professional Societies.

Kenya Chemical Society and

Royal Society of Chemistry

Education: PhD University of the Western Cape, South

Africa

Research focus; Finding scientific evidence on medicinal terrestrial plants and marine algae with therapeutic evidence

Recent Projects and consultancies;

1. Vulnerability of water quality and standards due to pollution in Mwea rice scheme, Kenya, June 2016

2. Antioxidant properties of selected aquatic flora by Kenya marine and Fisheries Institute (KEMFRI)

Conference presentations

1. Participation in a National in workshop on overview of trends in teaching and research in inorganic chemistry and its applications in Kenya (12-13 May 2016) at University of Nairobi

2. Isolation of phloroglucinol derivatives and a

sterol from the brown alga Ecklonia maxima, potential candidates for the effective treatment of cancer (02/11/2014-03/11/2014) at Addis Ababa -Ethiopia.

3. Phloroglucinol derivatives and a sterol from a brown alga $C E M-K$ in the management of Cancer (16 $\mathrm{t} h-18^{t} \mathrm{~h}$ October 2012; ASSAF

Recent Publications

Henry M. Mwangi, Wilfred T. Mabusela, Berhanu M. Abegaz and Onani O. Martin (2013). Antimicrobial activities of a novel biflavonoid and other constituents from Rhus natalensis. Journal of Medicinal Plants Research Vol. 7(10), pp. 619-623.

Henry M. Mwangi, Jan Van Der Westhuizen, Jeanine Marnewick, Wilfred T. Mabusela, Mwadham M. Kabanda, Eno E. Ebenso. (2013). Isolation, identification and radical scavenging activity of phlorotannin derivatives from brown algae, Ecklonia maxima: An experimental and theoretical study. Free Radicals and Antioxidants 3: S1-S10. http://dx.doi.org/10.1016/j.fra.2013.10.006

Mwadham M. Kabanda, Liliana Mammino, Lutendo C. Murulana , Henry M. Mwangi, and Wilfred T. Mabusela. (2014).Antioxidant radical scavenging properties of phenolic pent-4-en-1-yne derivatives isolated from Hypoxis rooperi. A DFT study in vacuo and in solution, International Journal of Food Properties, http://dx.doi.org/10.1080/10942912.2013.825842 Graduated and current supervision for Postgraduate Students

1. Maingi Mukora Francis (Msc) 184/33102/2015 Functionalized geopolymers derived from common clay and rice husk ash for application in adsorption of heavy metals

2. Constantine M. Kameti (Msc) I84/32256/2015 Anticancer, antimicrobial and antioxidant screening of compounds from selected medicinal plants used in Makueni county, Kenya.

3. Kipyegon Ng'eno (Msc) I84/32250/2015 Phytochemical screening, isolation and structure elucidation of compounds from selected medicinal plants traditionally used by Kipsigis in Kenya for antimicrobial and antioxidant activity

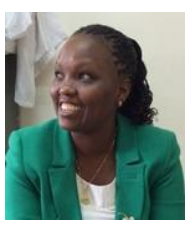

Germany
Third author

Name: Dr Margaret Mwihaki Ng'ang'a

Address: Box 53099 -00200 Nairobi or

43844-00100 Nairobi

Education Qualification

1. 2008: $\mathrm{PhD}$ in Natural Products Chemistry Kenyatta University with 6 months research visit to Paderborn University,

2. 1999: Master of Science (Chemistry), Kenyatta University

3. 1995: Bachelor of Education (Science), First class honors, Kenyatta University

Publications

1. Margaret Mwihaki Ng'ang'a, Hidayat Hussain, Sumesh Chhabra Caroline Langat-Thoruwa, Karsten Krohn, Javid Hussain, Ahmed-AlHarrasi, Ivan Robert (2012). Eucleanal: A new naphthalene derivative from Euclea divinorum. Natural Products Communications 7 (2): 193-194

2. Margaret Mwihaki Ng'ang'a, Hidayat Hussain, Sumesh Chhabra Caroline Langat-Thoruwa, Karsten Krohn, Javid Hussain, Ahmed-AlHarrasi, Ivan Robert (2012). Eucleanal A and B: Two new napthalene derivatives from Euclea divinorum. Chinese Chemical Letters 23: 576-578

3. Margaret Mwihaki Ng'ang'a, Hidayat Hussain, Sumesh Chhabra Caroline Langat-Thoruwa, Mohammed Riaz,Karsten Krohn, (2011). Drypetdimer A: A new flavones dimer from Drypetes gerrardi. Natural Products Communications 6: 1115-1116.

4. Margaret Mwihaki Ng'ang'a, Hidayat Hussain, Sumesh Chhabra Caroline Langat-Thoruwa, Beatrice Irungu, Ahmed Al-Harrasi Muhammed Riaz, Karsten Krohn (2012). Antiplasmodial activity of compounds from Drypetes gerrardi. Chemistry of Natural Compounds. 48: No. 2 (Russian Original No. 2 March -April 2012

5. Margaret Mwihaki Ng'ang'a, Hidayat Hussain, Sumesh Chhabra Caroline Langat-Thoruwa, Karsten Krohn (2009). Chemical constituents from the root bark of Ozoroa insignis. Biochemical Systematics and Ecology 37: 116-11.

6. Margaret Mwihaki Ng'ang'a, Sumesh Chhabra, Caroline Langat-Thoruwa, Hidayat Hussain Karsten Krohn (2008). Chemical constituents from the leaves of Drypetes gerrardii. Biochemical Systematics and Ecology 36: $320-322$.

Membership

Member Kenya Chemical Society (KCS),

$\square$ Member, Kenyatta University Alumni

$\square$ Member, Kenya DAAD Scholars Association (KDSA),

Member, DAAD Alumni, University Staff Development Program (UNISTAFF)

$\square$ Member, Natural Products of Eastern \& Central Africa (NAPRECA)

$\square$ Member, International Network of Women in Engineering and Science (INWES)

$\square$ Member, African Women in Science and Engineers (AWSE)

Achievements

1. 2012; Development of low cost diagnostic devicesfrom locally available materials that are biodegradable and can be incinerated (Ref. Grant number, 0153-01)

2. 2010: Development of simple on-host Behavioural manipulation tactics of controlling appendiculatus vector of the cattle disease of east coast fever (Grant no. NCST/5/003/w44) 